\title{
Influence of Chemical Treatments Sequence on Morphology and Crystallinity of Sorghum Fibers
}

\author{
Ismojo, Abdul Aziz Ammar, Ghiska Ramahdita*, Anne Zulfia, and Mochamad Chalid \\ Department of Metallurgy and Materials Engineering, Faculty of Engineering, Universitas Indonesia, \\ West Java, Depok 16424, Indonesia
}

Received August 2, 2017; Accepted January 10, 2018

\begin{abstract}
Microfibrillated cellulose (MFC) derived from natural fiber is continuously gaining interest to produce an environmentally friendly material, due to economic and ecological reasons. In consequence, sorghum is one of the most-cultivated crops that usually remain the waste as by product of bioethanol production. Indeed, it will be a promising area to utilize sorghum waste to produce MFC for enhancing polymer performance, especially in terms of crystallinity. The objective of this study is to investigate the effect of a sequence of chemical modification was applied to sorghum fibers, i.e. alkalization using $4 \%$ sodium hydroxide followed by bleaching using $1.7 \%$ sodium chlorite plus acetic acid as a buffer on morphology and crystallinity of sorghum fibers. The treatment was purposed to unbundle the lignocellulose networks into microfibrils cellulose with less amorphous part and lower hydrophilic properties. Evaluation of the chemical treatments effect on morphology, crystallinity index and chemical composition of sorghum fiber was measured via Field-Emission Scanning Electron microscope (FE-SEM), X-ray Diffraction (XRD) and Fourier Transformation Infra-Red (FTIR) Spectroscopy. The experiments show that treatments led to a removal of binding materials, such as amorphous parts hemicellulose and lignin, from the sorghum fibers, resulting MFC of sorghum fibers and enhanced crystallinity index from 41.12 to $75.73 \%$.
\end{abstract}

Keywords: microfibrillated cellulose (MFC); sorghum bagasse; chemical treatments; crystallinity index; FE-SEM; FTIR

\section{ABSTRAK}

Miikro-fibril selulosa (Microfibrillated cellulose-MFC) yang berasal dari serat alam telah menjadi perhatian untuk menghasilkan material yang ramah terhadap lingkungan, karena alasan ekonomis dan ekologis. Karena itu, sorghum sebagai salah satu tanaman yang paling banyak dibudidayakan biasanya menghasilkan sisa limbah dari produksi bio-etanol. Tentu saja ini akan menjadi daerah yang menjanjikan untuk memanfaatkan limbah sorgum untuk menhasilkan mikro-fibril selulosa guna meningkatkan sifat polimer, terutama dalam hal kristalinitas. Tujuan dari penelitian ini adalah untuk mengetahui pengaruh tahapan modifikasi kimia terhadap serat sorgum melalui perlakuan alkalinisasi dengan menggunakan larutan $4 \%$ berat natrium hidroksida yang dilanjutkan dengan perlakuan pemutihan dengan menggunakan larutan 1,7\% berat natrium klorida ditambah asam asetat yang berfungsi sebagai penyangga terhadap morfologi dan kristalinitas serat sorghum. Perlakuan tahapan kimia ini bertujuan untuk menguraikan jaringan lignoselulosa menjadi mikro-fibril selulosa dengan kadar bagian amorfus yang rendah dan menurunkan sifat hidrofiliknya. Evaluasi pengaruh perlakuan kimia terhadap morfologi, indeks kristalinitas dan komposisi kimia serat sorghum diukur melalui pengujian Field-Emission Scanning Electron microscope (FE-SEM), difraksi sinar-X (XRD) dan Fourier Transformation Infra-Red (FTIR). Percobaan menunjukkan bahwa perlakuan tahapan kimia dapat membuang material-material pengikat (seperti bagian amorf hemiselulosa dan lignin) dari serat sorgum sehingga menghasilkan mikro-fibril selulosa serat soghum dengan peningkatan indeks kristalinitas dari $41,12 \%$ menjadi $75,73 \%$.

Kata Kunci: mikro-fibril selulosa (MFC); ampas sorghum; perlakuan kimia; indeks kristalinitas; FE-SEM; FTIR

\section{INTRODUCTION}

Due to the increasing awareness to high consumption of products from non-renewable natural resources, natural fibers reinforced polymer composites have attracted many researchers' attention. This issue

* Corresponding author.

Email address : ghiska@metal.ui.ac.id; chalid@metal.ui.ac.id has been leading the industries of furniture, automotive, and packaging to search for a new form of fiber composites that can substitute the conventional composite material [1-3]. In recent years, some researchers have been focusing on how to obtain microfibrillated cellulose (MFC) from the natural fibers.

Ismojo et al. 
The advantages of this material are their abundant volume on the earth, renewable and biodegradable nature, lightweight, non-abrasive behavior to equipment and relative inexpensive [4-6].

As staple food, sorghum is an old world cereal that was domesticated in Africa and it becomes an important food crop and ranked after wheat, rice, corn, and barley, and it is cultivated in many countries [7]. One of distinctive properties of sorghum is its resistance to drought and tolerance to water logging. Sorghum also has a great potential to be developed in Indonesia because of its natural adaptation. It can be used as industrial raw materials such as sugar ants, amino acids, starch, among others, or fuel as bioethanol, and animal feed [8]. With regards to the potential development of sorghum in Indonesia, therefore, in year 2011, the Ministry of Research and Technology put in the $4^{\text {th }}$ range of their Roadmap program in food security after rice, corn and soybean.

On the previous research, natural fibers like flax, hemp, jute, sisal and "ijuk" have been proposed as great candidates as reinforcements in composite materials [910]. In 2015, Yuanita, et al. [4] investigated the preparation of MFC obtained from Arenga pinata or "ijuk" with multistage preparation of chemical treatment through alkalization, oxidation, and hydrolysis. That research resulted MFC fibers with diameter of 5-6 $\mu \mathrm{m}$ with increased crystallinity index of "ijuk" fiber. Another research in the same year reported that sorghum has higher cellulose and lowest lignin contents compared to the other agro-waste materials such as bagasse and rice straw [11]. Based on the investigations related to sorghum, this fiber might gain a chance to be another potential source of MFC. Recently, Ramahdita et al. [5] and Ismojo et al. [12] have investigated the preparation and characterization for sorghum-based MFC with chemical treatments (alkalization, bleaching and acid hydrolysis; and alkalization followed by acetylation, respectively). The study has produced MFC fibers with the smallest fiber size of 2-4 $\mu \mathrm{m}$ with highest crystallinity up to $44 \%$ and smallest fiber size of $5.5-6.5 \mu \mathrm{m}$ with highest crystallinity up to $80.64 \%$.

Since previous researches indicated that the preparation of MFC obtained from sorghum stalks waste is still limited, a study to give evidence effects of chemical treatment sequence to MFC preparation from sorghum stalks is an interesting research and we are still looking for the optimum chemical treatment type to obtain sorghum fiber with cellulose content which has a high crystalline structure. In the present work, we investigate the effect of chemical treatment sequence viz. alkalinization with 3 repeated cycles followed by bleaching with 3 repeated cycles to remove the amorphous parts in lignocellulose networks and to obtain the microfibrillation of cellulose fibers from sorghum fibers. Investigation has been evaluated in terms of the chemical contents, morphology and crystallinity of MFC.

\section{EXPERIMENTAL SECTION}

\section{Materials}

Stalk of sweet sorghum waste was obtained from a traditional market in Bogor, West Java. Sodium hydroxide $(\mathrm{NaOH})$ in pellets form, acetic acid $\left(\mathrm{CH}_{3} \mathrm{COOH}\right)$ and sodium chlorite $\left(\mathrm{NaClO}_{2}\right)$ solution was purchased from Merck.

\section{Instrumentation}

Characterization of morphology, chemical contents and crystallinity using FE-SEM FEI Inspect F50, Spectrum Two ${ }^{\mathrm{TM}}$ Infrared Spectrometer Perkin Elmer (ASTM E 1252) and Shimadzu XRD-7000 X-Ray Diffractometer instruments were carried out in the Metallurgy and Materials Engineering, Universitas Indonesia. FE-SEM was used to characterized and determine microstructure changes of sorghum fibers after sequence chemical treatment and FTIR and XRD were used to characterized and determine the crystallinity of untreated sorghum and treated sorghum. Crystallinity of sorghum fibers, using XRD, was determined by virtue on reflected intensity data from method of Segal et al. [13]

$\mathrm{Cl}(\%)=\frac{\mathrm{I}(002)-\mathrm{I}(\mathrm{amp})}{\mathrm{I}(002)}=100$

where $\mathrm{Cl}$ is Crystallinity Index, $\mathrm{I}_{(002)}$ is the maximum intensity which located at angle around $2 \theta=22^{\circ}$ and $I_{(a m p)}$ is the intensity scattered by amorphous part of the sample at the diffraction angle around $2 \theta=18^{\circ}$.

\section{Procedure}

\section{Preparation of sorghum fibers}

The stalk sweet sorghum waste were cut into \pm $5 \mathrm{~cm}$ and crushed until passing 40 mesh size screens. Afterwards, sorghum fibers were weighed and washed, then ready for a sequence of chemical treatments.

\section{Chemical treatments of sorghum fibers}

The first chemical treatment was alkalization, and followed by bleaching proses. The alkalization samples were prepared by soaking sorghum fibers in $4 \%(\mathrm{w} / \mathrm{w})$ sodium hydroxide in agitated condition for $3 \mathrm{~h}$ at temperature around $70-90{ }^{\circ} \mathrm{C}$ in 3 repeated cycles. Bleaching treatment was carried out after alkalization by soaking in $1.7 \%(w / w) \mathrm{NaClO}_{2}+0.2 \mathrm{CH}_{3} \mathrm{COOH}$ (as a buffer, $\mathrm{pH} 4.5$ ) solutions in agitated condition for $4 \mathrm{~h}$ 
at temperature around $70-90{ }^{\circ} \mathrm{C}$ in 3 repeated cycles. After each cycle of the treatment, samples were washed with deionized water until reached neutral $\mathrm{pH}$ and filtered. The final step is drying the samples at room temperature and carefully kept in a dry container prior to characterizations.

\section{RESULT AND DISCUSSION}

\section{Compound in Sorghum}

Chemical treatment sequence of MFC from sorghum fibers with 3 repeated cycle of alkalization followed by 3 repeated cycles of bleaching might transform the compounds in sorghum fibers. We analyzed the chemical composition of the sorghum fibers without treatment and by alkalization and alkalization + bleaching treatment using FT-IR spectroscopy, as shown in Fig. 1.

The peaks in Fig. 1 marks the absorption band corresponding to the various chemical bonds of sorghum fibers before and after chemical treatment sequence. The untreated sorghum for wavenumbers 1300-1000 $\mathrm{cm}^{-1}$ which is related to $\mathrm{C}-\mathrm{O}$ stretch part of hemicellulose, pectin and lignin [4-6] and wavenumbers $1421 \mathrm{~cm}^{-1}$ is associated with $\mathrm{C}-\mathrm{H}$ in-plane deformation by aromatic ring stretching [14]. The other wavenumbers at around 2930-2910 $\mathrm{cm}^{-1}$ indicate the $\mathrm{C}-\mathrm{H}$ stretching vibration of carbonyl aldehyde in lignin [15] and wavenumbers at around $3600-3000 \mathrm{~cm}^{-1}$ indicate the $\mathrm{OH}$ stretching in cellulose and/or hemicellulose [16].

According to procuring MFC, this study compared untreated sorghum fiber with sequence chemical treatment viz. alkalization 3 cycles and alkalization followed bleaching 3 cycles in removing impurities such as wax and oil in the surface lignin and hemicellulose in the cell wall of sorghum fibers. The IR-spectrum for sorghum fibers treated with alkalization + bleaching showing a decrease in intensity of the vulnerable wavelength at around $1300-1000 \mathrm{~cm}^{-1}$. This suggests that some of the lignin and hemicellulose is removed from sorghum fibers during alkalization and alkalization + bleaching treatment. From these results, we conclude that alkaline treatment causes the loss of binding materials such as hemicellulose, pectin, and lignin, from sorghum fiber bundles. The loss of this bonding material causes the separation of the fiber bundle into a basic or fibrillated fiber [16].

\section{Morphology}

The FE-SEM image, Fig. $2 a-2 c$, shows that the sorghum fiber bundle becomes fibrillated during the alkalinization treatment process and further fibrillated after undergoing alkalinization followed by bleaching treatment. The surface morphology of sorghum fibers without treatment can be seen in Fig. 2a. The figure shows that the appearance of surface untreated sorghum fibers are still seen rough with large in diameter

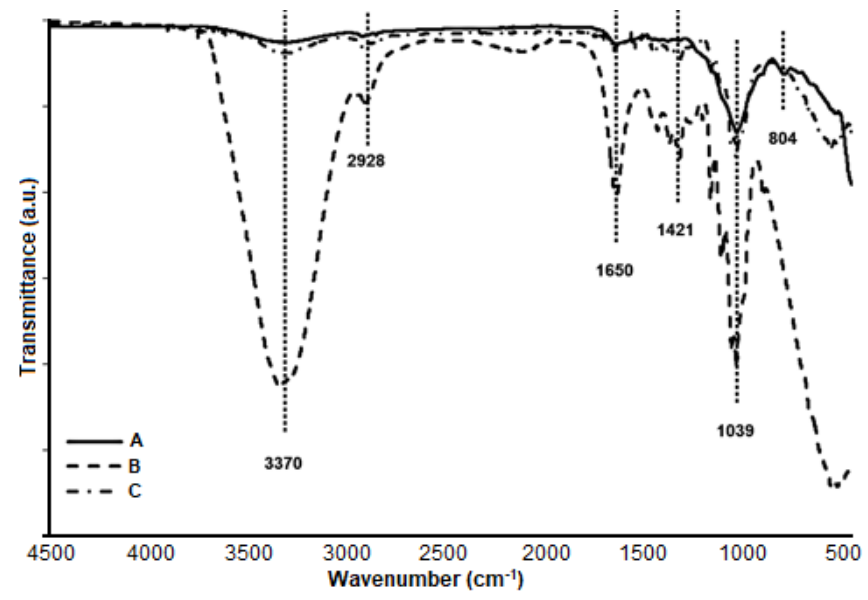

Fig 1. FTIR spectra of $A$ ) untreated sorghum, B) alkalization treated sorghum, and C) alkalization + bleaching treated sorghum
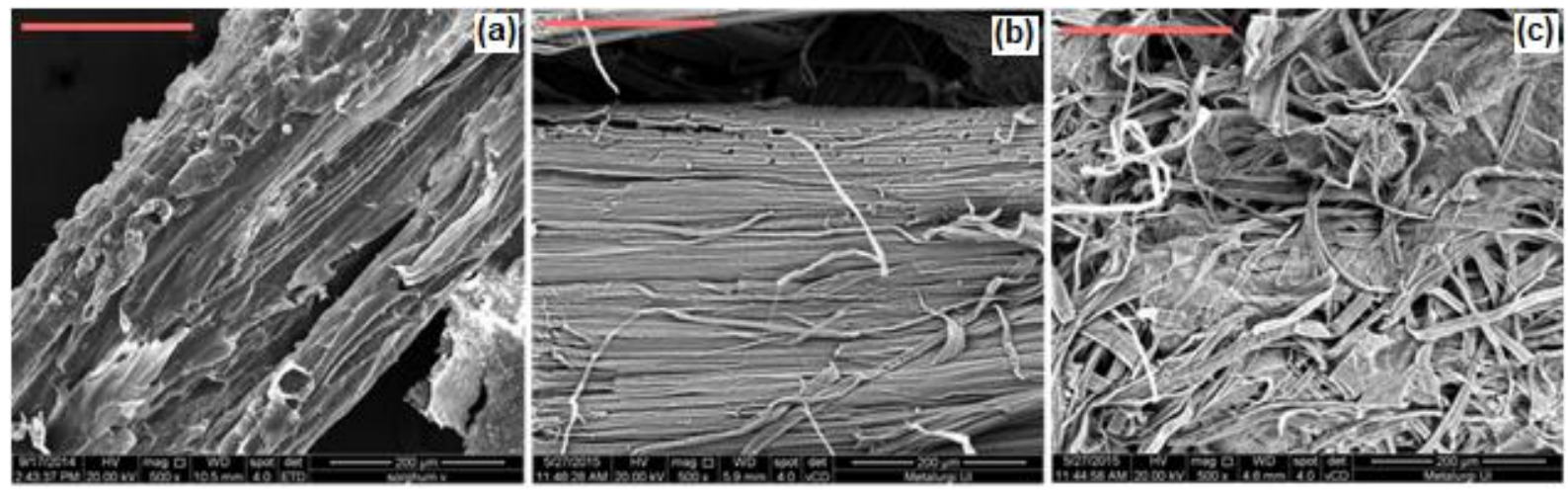

Fig 2. FE-SEM image of sorghum fibers, (a) untreated sorghum fiber surface, (b) 3 cycles alkalization sorghum fiber surface, (c) 3 cycle alkalization + bleaching sorghum fiber surface. Red bar scale represents $200 \mu \mathrm{m}$ 


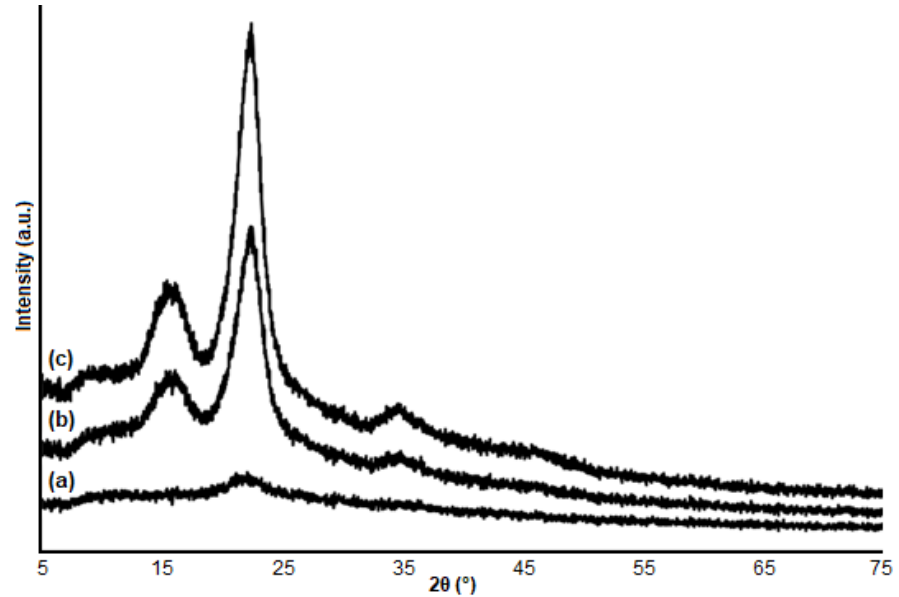

Fig 3. X-ray diffraction pattern of sorghum fibers (a) untreated, (b) alkalization treated, and (c) alkalization + bleaching treated

size for about $200 \mu \mathrm{m}$, like a single fibers, and the surfaces were still covered by waxes as impurities. Alkali treatment (4 wt\% $\mathrm{NaOH}$ ) causes sorghum fibers to be cleaner and some fibers begin to be fibrillated into basic fibers (Fig. 2b). A possible explanation is that the binding materials such as pectin, lignin, and hemicellulose have been released from sorghum fiber during alkaline treatment, which causes fibrillation and fiber into a fiber bundle solving basic [17]. Bleaching treatment process with $1.7 \% \mathrm{NaClO}_{2}$ for $4 \mathrm{~h}$ with 3 cycles in sorghum fiber after alkalinization treatment is shown in the Fig. 2c. In this case, the treatment causes the sorghum fibers to become cleaner and more fibrillated into the basic fibers (microfibrils). The bleaching has significant effects in order to remove lignin and hemicellulose as confirmed by FTIR in Fig. 1 and separation of single micro fibrils with the smallest fibers about $10 \mu \mathrm{m}$.

\section{Crystallinity}

Most cellulose structures consist of crystalline and amorphous parts, in various proportions depending on source and pretreatment preparation process, where the lignin and hemicellulose are amorphous structure. The XRD pattern of untreated and alkalization followed by bleaching sorghum fibers are showed in Fig. 3. This treatment caused the sorghum fibers to lose most of the lignin and hemicellulose and along with the diminished amorphous portion contained in the sorghum fiber will increase the semi-crystalline cellulose portion. The increase of the crystalline part on sorghum fibers can be clearly seen with the XRD characterization result as shown in Fig. 3. The spectrum of sorghum fibers without treatment shows three major peaks at about 16.0, 22.0, and $34.0^{\circ}$. These peaks are associated with the cellulose crystal structure I in the field reflections (10 $\overline{1})$,

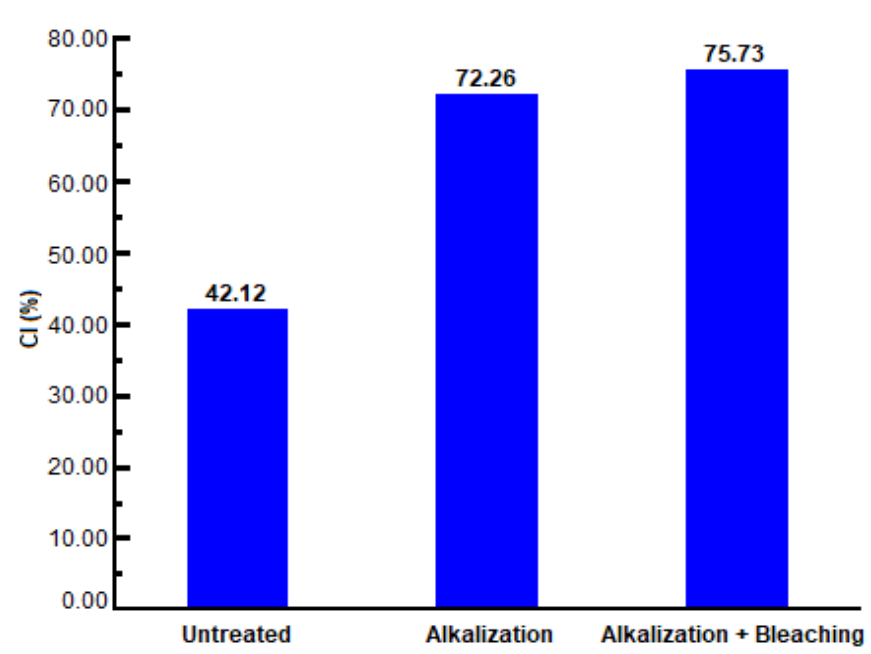

Fig 4. $\mathrm{Cl}$ of untreated, alkalization and alkalization + bleaching treatments of sorghum fibers

(002), and (040), respectively [18]. In the case of sorghum fibers treated with alkalization and alkalization + bleaching, the peak in the (002) plane becomes sharper than the fiber without treatment [19]. We hypothesize that alkaline and alkaline + bleaching treatments increase cellulosic crystallinity by removing some parts of the chemical component, such as hemicellulose, pectin, and lignin; thus, the cellulose content increases, so that the peak in the (002) plane becomes sharper.

The highest intensity of sorghum fibers was obtained from alkalization treatment followed with bleaching process. Fig. 4 shows the comparisons of the crystallinity index, obtained from both modification treatments with the untreated sorghum fibers. The value was extracted from XRD curves using equation (1). As seen in Fig. 4, the most effective way to remove the amorphous parts in sorghum fibers was by alkalization treatment followed by bleaching process.

\section{CONCLUSION}

Microfibrils cellulose from sorghum fibers has been successfully obtained through 3 repeated cycles of alkalization and followed by 3 repeated cycles of bleaching. Both modification treatments have significantly removed impurities that cover the sorghum fibers surface, such as wax. Moreover, the treatments enable the removal of the amorphous parts, which are lignin and hemicellulose in the cell wall of the sorghum fibers. This study also shows that MFC of sorghum fibers with the smallest fibers is about $10 \mu \mathrm{m}$ with an enhanced crystallinity index from 41.12 to $75.73 \%$ due to alkalization + bleaching treatment with 3 repeated cycles. In the future studies, we will investigate the effect of sorghum fibers as reinforcement with high 
crystallinity of the cellulose to the compatibility of the synthetic polymer matrix.

\section{REFERENCES}

[1] Cai, M., Takagi, H., Nakagaito, A.N., Li, Y., and Waterhouse, G.I.N., 2016, Effect of alkali treatment on interfacial bonding in abaca fiber-reinforced composites, Composites Part A, 90, 589-597.

[2] Bachtiar, D., Sapuan, S.M., and Hamdan, M.M., 2008, The effect of alkaline treatment on tensile properties of sugar palm fiber reinforced epoxy composites, Mater. Des., 29 (7), 1285-1290.

[3] Mylsamy, K., and Rajendran, I., 2011, Influence of alkali treatment and fibre length on mechanical properties of short Agave fibre reinforced epoxy composites, Mater. Des., 32 (8-9), 4629-4640.

[4] Yuanita, E., Pratama, J.N., Mustafa, J.H., and Chalid, M., 2015, Multistages preparation for microfibrillated celluloses based on Arenga pinnata “ijuk" fiber, Procedia Chem., 16, 608-615.

[5] Ramahdita, G., IImiati, S., Suryanegara, L., Khalid, A., and Chalid, M., 2017, Preparation and characterization for sorgum-based micro-fibrillated celluloses, Macromol. Symp., 371, 69-74.

[6] Yuanita, E., Hendrasetyawan, B.E., Firdaus, D.F., and Chalid, M., 2017, Improvement of polypropylene (PP)-modified bitumen through lignin addition, IOP Conf. Ser. Mater. Sci. Eng., 223 (1), 12028.

[7] Dahlberg, J., Berenji, J., Sikora, V., and Latković, D., 2011, Assessing sorghum [Sorghum bicolor (L) Moench] germplasm for new traits: Food, fuels \& unique uses, Maydica, 56 (1750), 85-92.

[8] Irawan, B., and Sutrisna, N., 2011, Prospek pengembangan sorgum di Jawa Barat mendukung diversifikasi pangan, FAE, 29 (2), 99-113.

[9] Kabir, M.M., Wang, H., Lau, K.T., and Cardona, F., 2012, Chemical treatments on plant-based natural fiber reinforced polymer composites: An overview, Composites Part B, 43 (7), 2883-2892.

[10] Chalid, M., and Prabowo, I., 2015, The effects of alkalization to the mechanical properties of the ijuk fiber reinforced PLA biocomposites, Int. J. Chem.
Mol. Nucl. Mater. Metall. Eng., 9 (2), 342-346.

[11] Kumar, A., Negi, Y.S., Choudhary, V., and Bhardwaj, N.K., 2014, Characterization of cellulose nanocrystals produced by acid-hydrolysis from sugarcane bagasse as agro-waste, J. Mater. Phys. Chem., 2 (1), 1-8.

[12] Ismojo, Simanulang, P.H., Zulfia, A., and Chalid, M., 2017, Preparation of micro-fibrillated cellulose from sorghum fiber through alkalization and acetylation treatments, IOP Conf. Ser. Mater. Sci. Eng., 223 (1), 012057.

[13] Segal, L., Creely, J.J., Martin, A.E., and Conrad, C.M., 1959, An empirical method for estimating the degree of crystallinity of native cellulose using the X-ray diffractometer, Text. Res. J., 29 (10), 786794.

[14] Yan, Z., Li, J., Li, S., Chang, S., Cui, T., Jiang, Y., Cong, G., Yu, M., and Zhang, L., 2015, Impact of lignin removal on the enzymatic hydrolysis of fermented sweet sorghum bagasse, Appl. Energy, $160,641-647$.

[15] Ahmed, A.S., Islam, M.S., Hassan, A., Haafiz, M.K.M., Islam, N., and Arjmandi, R., 2014, Impact of succinic anhydride on the properties of jute fiber/polypropylene biocomposites, Fibers Polym., 15 (2), 307-314.

[16] Célino, A., Gonçalves, O., Jacquemin, F., and Fréour, S., 2014, Qualitative and quantitative assessment of water sorption in natural fibers using ATR-FTIR spectroscopy, Carbohydr. Polym., 101, 163-170.

[17] Kalia, S., Kaith, B.S., and Kaur, I., 2009, Pretreatments of natural fibers and their application as reinforcing material in polymer composites-A review, Polym. Eng. Sci., 49 (7), 1253-1272.

[18] Oudiani, A.E., Chaabouni, Y., Msahli, S., and Sakli, F., 2011, Crystal transition from cellulose I to cellulose II in $\mathrm{NaOH}$ treated Agave americana L. fiber, Carbohydr. Polym., 86 (3), 1221-1229.

[19] Kobayashi, K., Kimura, S., Togawa, E., and Wada, M., 2011, Crystal Transition from Na-cellulose IV to cellulose II monitored using synchrotron X-ray diffraction, Carbohydr. Polym., 83 (2), 483-488. 